\author{
Beevenom 처리가 돼지의 체내 면역반응에 미치는 효과 \\ 조성구* . 김경수** . 이석천* \\ 충북대학교 축산학과*, (주)오비티**
}

\title{
Effects of Natural Honeybee (Apis mellifera ligustica) Venom Treatment on the Humoral Immune Response in Pigs
}

\author{
S. K. Cho*, K. S. Kim** and S. C. Lee* \\ Dept. of Animal Science, Chungbuk National University*, OBT, Inc., Chungbuk Jincheunkun, Korea**
}

\begin{abstract}
This experiment was carried out to investigate effects of honeybee venom treatment on the humoral immune response in pigs.

To investigate effects of natural honeybee venom on the concentration of immunoglobulin $\mathrm{G}, \mathrm{A}$, and $\mathrm{M}$, 20 piglets $(\mathrm{LY} \times \mathrm{D})$ from 3 sows were allocated into two groups bee venom-treated group $(10$ piglets $)$ and non-treated control(10 piglets). Natural honeybee venom was treated at 0, 3, 6 days after birth and the acupoints were Hai-men(ST-25), Du-kou(CV-8) and Jiao-chao(GV-1) points at 0, 3 days after birth and the regions of castration and tail amputation point at 6 days. Control group was injected $1 \mathrm{~m} \ell$ of saline to the same site. Concentrations of IgG, $\mathrm{A}$, and $\mathrm{M}$ were measured with immunoturbidimetric method at $0,3,7$, 14, and 21 days after treatment. To investigate the effect of bee venom on the production of antibodies against hog cholera and atrophic rhinitis vaccines that were used as indicator antigens, 40 piglets(LYxD) from 5 sows were grouped as bee venom-treated group (20 piglets) and control group(20 piglets). Natural honeybee venom was treated at 0 , 3days(castration, tail amputation) and 21days after birth. The acupoints were Hai-men(ST-25), Du-kou(CV-8) and Jiao-chao (GV-1) points at 0 day, the regions of castration and tail ampution at 3 days and Jiao-chao(GV-1) and Bai-hui(GV-20) points at 21days after birth(weaning). Control group was injected $1 \mathrm{ml}$ of saline to the same site. Atrophic rhinitis vaccine was injected twice at 24 and 44 days after birth and hog cholera vaccine was also injected twice at 44 and 64 days after birth. Antibody titers against Bordetella bronchiseptica and hog cholera virus were measured by using tube agglutination and ELISA tests at 24, 34, 44, 54 and 74 days after birth.

Concentrations of IgG of treated group were 339.52, 366.48, 296.52, 242.06 and $219.06 \mathrm{mg} / \mathrm{dl}$ at $0,3,7$, 14 and 21 days after birth, respectively. In contrast, concentrations of IgG in control group were respectively 347.10, 334.14, 243.28, 205.18 and $191.58 \mathrm{mg} / \mathrm{dl}$ during same periods with treated group. Concentrations of IgG at 0 day was not significantly different between the treated group and control group but treated group were significantly increased by $10.28 \%$ at 3 days after birth $(\mathrm{P}<0.02), 21.88 \%$ at 7 days after birth $(\mathrm{P}<0.01), 18.0 \%$ at 14 days after birth $(\mathrm{P}<0.07)$ and $14.3 \%$ at 21 days after birth $(\mathrm{P}<0.01)$. Concentrations of IgA and Ig $\mathrm{M}$ were not significantly different. Antibody titers against hog cholera virus were significantly increased by $57.0 \%$ at 24 days after birth( $(\mathrm{P}<0.03), 74.6 \%$ at 34 days after birth $(\mathrm{P}<0.006), 48.6 \%$ at 44 days after birth $(\mathrm{P}<0.017), 45.0 \%$ at 54 days after birth $(\mathrm{P}<0.16)$ and $44.4 \%$ at 74 days after birth $(\mathrm{P}<0.006)$ in bee venom treated group in comparison with control group. Antibody titers against the Bordetella bronchiseptica was significantly increased in Beevenom treated group as $9.1 \%$
\end{abstract}

Corresponding author : S. K. Cho, Dept. of Animal Sci. Chung-Buk National University, Kaesin-dong, Cheongju, 361-763, Korea.

phone : 043-261-2551. E-mail : deercho@chungbuk.ac.kr 
$(\mathrm{P}<0.32)$ at 24 days, 39.7\% ( $<<0.002)$ at 34 days, 31.9\% ( $<0.02)$ at 44 days, 33.4\% $(\mathrm{P}<0.01)$ at 54 days and $57.3 \%(\mathrm{P}<0.007)$ at 74 days after birth when compared with those of control group pigs.

Collecting together, the results in this study showed that immune responses were increased by treatment of natural honeybee venom to pigs. These results suggested that the treatment of bee venom could be used effectively for the increase of productivity in livestock industry.

(Key words : Honeybee venom, Immunoglobulin, Acupoints, Jiao-chao)

\section{I. 서 론}

현대와 미래의 양돈 산업은 고품질의 안전한 돈육생산 형태로 새롭게 변화되고 있다. 그러 나 대형화 사육체계는 다양한 질병의 발생빈도 를 증가시킴에 따라 양돈 수익성에 영향을 미 치기 때문에 이에 대한 안전성 있는 대책이 요 구되고 있다. 돼지의 다양한 질병과 다발성 질 병의 치료 및 예방을 위하여 1950년대 이후 오 늘에 이르기 까지 항생물질을 축산에 이용하면 서 가축질병 치료 및 예방효과로 축산물의 생 산성을 높여주는데 많은 공헌을 하였는데, 항 생물질을 장기적으로 투여하면서 다양한 문제 점이 발생되어 종류별 사용방법이 엄격히 제한 되고 있다. 또한 축산물의 안전성 관점에서 최 근 세계 주요 국가에서는 축산물 내에 항생물 질과 설파제 등의 잔류량 규제도 엄격해지고 있다. 이에 대하여 우리나라에서도 그 종류와 허용 기준치를 정하여 사용 및 잔류량을 규제 하고 있기 때문에 항생물질을 대체 할 수 있는 효과적인 방법에 대하여 연구의 필요성이 시급 하게 되었다. 그 방안의 일종으로서 꿀벌의 생 봉독 활용에 대하여 연구가 이루어져 실제 축 산에 응용한 성과가 보고되고 있다(조 등, 1998; 최 등, 1998 ; 강 등 1999 ; 조 등, 2005) 이들의 보고서에 의하면 꿀벌의 봉독은 벌이 분비하는 천연생리활성 물질로서 돼지에 사용 하면 항생물질의 첨가로 야기될 수 있는 여러 가지 부작용 없이 가축의 질병예방은 물론, 성 장촉진 및 사료효율 개선에 큰 효과가 있다고 보고 하였다.

꿀벌의 봉독에 대하여 최근에는 다양한 실험 결과가 보고되고 있다. 현재까지 밝혀진 봉독의 특성으로서 봉독을 조성하는 물질은 melittin, apamin, adolapin 등과 같은 peptide 류(Jentsch, 1969 ; Harberman 등, 1965 ; Hanson 등, 1974 ;
Shkenderov, 1973, 1982 ; Gauldie 등, 1976, 1978 ; Peck 등 1978 ; Lowy, 1971 ; Vick, 1972)가 있 고, hyaluronidase와 phospholipase $\mathrm{A}_{2}$ 등과 같은 효소류(Baker, 1966 ; Jentsch, 1972 ; Shkenderov, 1979 ; Doery, 1964)가 함유되어 있고, histamin 과 dopamine 및 norepinephirine 등과 같은 생리 학적 활성 아민류 (Owen, 1971, 1974 ; Owen 등 1982)와 약간의 탄수화물과 비 peptide류 성분 (O'Conner 등, 1978 ; Nelson, 1963) 등의 복합 물질로 약 23종의 성분이 분석되었다. 꿀벌 봉독의 주요한 생체내에서의 기능은 항염증 작용(Dunn 등, $1988^{\mathrm{a}}$ ), 항균작용(Vick 등, 1972 ; Steiner 등, 1982 ; Dunn 등, $1988^{\mathrm{b}}$ ), 용혈작용 (Rudenco 등, 1996), 면역기능 증강작용(Artemov 등, 1967 ; Hoffmann 등, 1997 ; Curcio 등, 1997), 방사선 장해 보호작용(Peck 등, 1978 ; Jentsch, 1969), 신경통 완화작용, 진통작용, 신경독 작용 (Harbermann 등, 1965) 등의 다양한 작용이 복합 적으로 작용하는 것으로 밝혀져 있다. 최근 돼 지 등의 가축에 생봉독을 이용한 연구가 시작 되어 동물의 성장촉진, 면역기능 증강, 각종 질 병치료 및 예방 등의 유효성이 보고(Belliveau, 1982 ; Kim, 1986, 1987 ; 김, 1992 ; 조 등, 1998, 2005 ; 최 등, 1998 ; 강 등, 1999) 되고 있다.

Hoffmann 등(1997)과 Curcio 등(1997)은 봉독 이 체액성 면역반응을 증강시켜 면역력 상승에 효과적이었다고 하였으며, Light 등(1977)에 의 하면 양봉관리자나 봉독 시술을 장기간 받은 사람에서 Immunoglobulin G 항체 농도가 증가 하였다고 보고하였다. Immunoglobulin(Ig)은 외 부의 이물질로부터 생체를 방어하는 역할을 하 는 물질로서 혈액, 체액, 점막, 눈물, 땀 등에 존재하고 heavy chain 구조에 따라 IgG, IgA, $\operatorname{IgM}, \operatorname{IgD}, \operatorname{IgE}$ 등으로 구분된다(Benjamini 등, 1996).

본 실험에서는 생봉독을 돼지에 주입하였을 
때 봉독을 처리하지 않은 돼지들에 비하여 생 봉독을 처리한 돼지들의 면역항체 수준에서 어 떠한 변화를 나타내는지 확인하기 위하여 Ig 중 체내 면역체계에서 중요한 작용을 하는 $\mathrm{IgG}$, $\operatorname{IgA}$, IgM 등 3종을 선택하여 농도변화를 조사 하였다. 그러나 봉독 그 자체가 항원이므로 봉 독으로 인한 Ig 농도변화를 면역능력 증감으로 받아들이기에는 불충분한 면이 있기 때문에 지 표항원을 사용하여 그 지표항원에 대한 항체생 산에 어떠한 영향을 미치는가에 대한 실험이 요구된다. 따라서 본 실험에서는 지표항원으로 현재 실제 양돈장에서 가장 문제가 되고 있고 예방접종을 필수적으로 실시하는 돈콜레라와 위축성비염 백신을 지표항원으로 선택하여 생 봉독 처리 후 지표항원에 대한 항체생산 반응 을 조사하였다.

\section{ㅁ. 재료 및 방법}

\section{1. 공시동물}

Ig 농도 측정을 위하여 랜드레이스 $\times$ 요크셔 (LY) 1대잡종 모돈 3두에서 생산된 3원 교잡종 자돈(LYD) 20 두를 공시하였고, 동복자돈을 처 리군과 대조군에 $1 / 2$ 씩 배치하였다. 또한 돈 콜 레라(HC)와 위축성비염(AR)에 대한 항체가 측 정 실험을 위해 랜드레이스 $\times$ 요크셔 1 대잡종 (LY) 모돈 5두에서 생산된 3원 교잡종 자돈 (LYD) 40 두를 공시하고 동복 자돈을 처리군과 대조군에 각각 $1 / 2$ 씩 배치하였다.

\section{2. 실험기간}

Ig 농도측정 실험은 30 일간 실시하였고, 돈콜 레라와 위축성비염 백신에 대한 항체가 측정 실험은 90 일간 실시하였다.

\section{3. 실험장소}

Ig 농도 측정을 위한 실험돼지 사육은 전업 양돈장에서 하였고, 혈중 Ig 농도 분석은 이원 의료재단에서 실시하였으며, $\mathrm{HC}$ 와 $\mathrm{AR}$ 에 대한
항체가 측정을 위한 실험처리 역시 전업 양돈 장에서 하였고, 항체가 분석은 충청북도 축산 위생연구소 위생과에서 실시하였다.

\section{4. 실험설계}

(1) $\lg$ 농도측정 실험

모돈 3 두의 자돈 중 20 두를 무작위로 선택하 여 동복자돈이 생봉독 처리군과 대조군에 같은 수가 배치되도록 했고 생봉독 처리군에 3복 10 두, 대조군에 3 복 10 두를 배치하였다(Table 1).

Table 1. Experimental design for measuring of Immunoglobulin concentration (head)

\begin{tabular}{cccccccc}
\hline \multirow{2}{*}{ Litter } & \multicolumn{3}{c}{ Treatment } & & \multicolumn{3}{c}{ Control } \\
\cline { 2 - 4 } \cline { 6 - 8 } & Male & Female & Total & & Male & Female & Total \\
\hline \hline 1 & 2 & 2 & 4 & & 2 & 2 & 4 \\
2 & 2 & 1 & 3 & & 1 & 3 \\
3 & 1 & 2 & 3 & & 1 & 2 & 3 \\
\hline Total & 5 & 5 & 10 & & 5 & 5 & 10 \\
\hline
\end{tabular}

(2) $\mathrm{HC}, \mathrm{AR}$ 항체가 분석실험

모돈 5 두의 자돈 중 40 두를 무작위로 선택하 여 동복자돈이 생봉독 처리군과 대조군에 같은 수가 배치되도록 했고 생봉독 처리군에 5복 20 두, 대조군에 5복 20 두를 배치하였다(Table 2).

Table 2. Experimental design for immune responses against hog cholera and atrophic rhinitis vaccines $^{1)} \quad$ (head)

\begin{tabular}{ccccccccc}
\hline \multirow{2}{*}{ Litter } & \multicolumn{3}{c}{ Treatment } & & \multicolumn{3}{c}{ Control } \\
\cline { 2 - 3 } \cline { 6 - 8 } & Male & Female & Total & & Male & Female & Total \\
\hline \hline 1 & 3 & 2 & 5 & & 3 & 2 & 5 \\
2 & 2 & 2 & 4 & & 2 & 2 & 4 \\
3 & 2 & 1 & 3 & & 2 & 1 & 3 \\
4 & 2 & 2 & 4 & & 2 & 2 & 4 \\
5 & 2 & 2 & 4 & & 2 & 2 & 4 \\
\hline Total & 11 & 9 & 20 & & 11 & 9 & 20 \\
\hline 1 1) Vaccination & & & & &
\end{tabular}

1) Vaccination

Hog cholera vaccine (Bayer Korea) was injected at 44 and 64 days after birth.

Artropic rhinitis vaccine (Hemo PR, Bayer Korea) was injected at 24 and 44 days after birth. 


\section{5. 생봉독 처리}

(1) Ig 농도 측정실험을 위한 생봉독 처리 생봉독은 죽중과 고교(1984) 및 이와 원 (1989)의 침구 경혈부위에 생봉독을 생시와 3일 령, 6일령 및 단미, 거세시술 시에 처리하였다. 생시와 3일령 때는 면역증강을 목적으로 교소 혈 (GV-1, Jiao-chao 항문과 꼬리의 중간 함몰 부), 해문혈 (ST-25, Hai-men, 배꼽좌우 $1 \mathrm{~cm}$ ), 두구혈 (CV-8, Du-kou, 배꼽 중앙) 부위 살아있 는 일벌 1 마리씩을 직접 쏘이게 하여 봉침을 통하여 봉독이 투입되도록 하였으며, 6일령 때 는 거세, 단미 부위에 각 1 마리를 시술하였고 시술 혈위는 Table 3 및 Fig. 1, 2와 같다.

Table 3. Acupoints of honeybee venom treatment according to different stage for Ig concentration measurement

\begin{tabular}{cll}
\hline $\begin{array}{c}\text { Days } \\
\text { after birth }\end{array}$ & Acupoints & \multicolumn{1}{c}{ Location } \\
\hline \hline & $\begin{array}{l}\text { ST-25 } \\
\text { (Hai-men) })\end{array}$ & $\begin{array}{l}\text { About 1cm both sides } \\
\text { (left, right) to the umbilicus }\end{array}$ \\
0,3 & $\begin{array}{l}\text { CV-8 } \\
\text { (Du-kou) } \\
\text { GV-1 } \\
\text { (Jiao-chao) }\end{array}$ & $\begin{array}{l}\text { Center of umbilicus } \\
\text { Indentation point between the } \\
\text { bail and the anus }\end{array}$ \\
6 & & Castration and tail amputation \\
\hline
\end{tabular}

Table 4. Acupoints of honeybee venom treatment according to different stage for antibody titer measurement

\begin{tabular}{|c|c|c|}
\hline $\begin{array}{c}\text { Days } \\
\text { after birth }\end{array}$ & Acupoints & Location \\
\hline \multirow{3}{*}{0} & $\begin{array}{l}\text { ST-25 } \\
\text { (Hai-men) }\end{array}$ & $\begin{array}{l}\text { About } 1 \mathrm{~cm} \text { both sides } \\
\text { (left, right) to the umbilicus }\end{array}$ \\
\hline & $\begin{array}{l}\text { CV-8 } \\
\text { (Du-kou) }\end{array}$ & Center of umblicus \\
\hline & $\begin{array}{l}\text { GV-1 } \\
\text { (Jiao-chao) }\end{array}$ & $\begin{array}{l}\text { Indentation between the base } \\
\text { of tail and the anus }\end{array}$ \\
\hline 3 & & Castration and tail ampution \\
\hline \multirow[b]{2}{*}{21} & $\begin{array}{l}\text { GV-1 } \\
\text { (Jiao-chao) }\end{array}$ & $\begin{array}{l}\text { Indentation part between the } \\
\text { base of tail and the anus }\end{array}$ \\
\hline & $\begin{array}{l}\text { GV-20 } \\
\text { (Bai-hui) }\end{array}$ & $\begin{array}{l}\text { Junction of lumbar and sacral } \\
\text { vertebrae alone the medial } \\
\text { plane }\end{array}$ \\
\hline
\end{tabular}

(2) $\mathrm{HC}$ 와 $\mathrm{AR}$ 항체가 측정실험을 위한 생봉 독 처리

$\mathrm{HC}$ 와 $\mathrm{AR}$ 항체가 측정실험을 위한 생봉독 처리구는 생시와 3 일령 (단미, 거세 시) 및 21일 령 (이유 시)에 시술하였다. 생시에는 면역증강 을 목적으로 교소혈, 해문혈 및 두구혈위에 살 아있는 일벌 1 마리씩 직침하였다. 3 일령 시에는 거세 단미 부위에 각 1 마리, 21 일령 시에는 이 유 및 이동 스트레스를 경감시키기 위하여 교 소혈, 백회혈에 각각 생봉 1 마리를 직침하였다. 시술 혈위는 Table 4 및 Fig. 1, 2, 3과 같다.

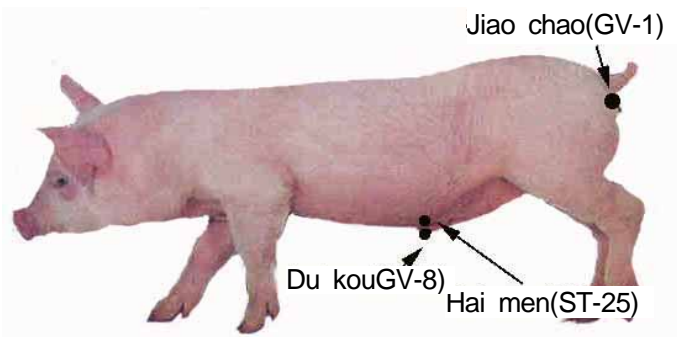

Fig. 1. Acupoints for honeybee venom treatment of piglet at birth(for measurement Ig and $\mathrm{HC}, \mathrm{AR}$ antibody titer) and 3days after birth(for measurement Ig).

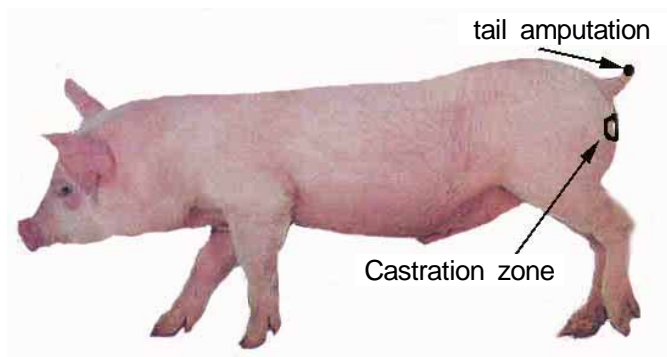

Fig. 2. Acupoints for honeybee venom treatment of piglet at 3(for measurement $\mathrm{HC}, \mathrm{AR}$ antibody titer) and 6days after birth (for measurement Ig).

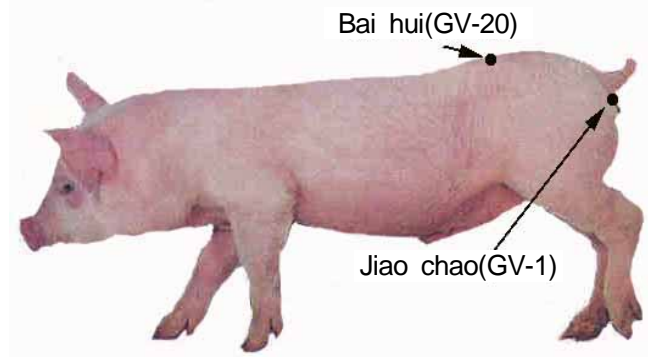

Fig. 3. Acupoints for honeybee venom treatment of piglet at 21days after birth (for measurement $\mathrm{HC}, \mathrm{AR}$ antibody titer). 


\section{6. 시술용 생봉선택과 생봉독 처리방법}

\section{(1) 시술용 생봉선택}

생봉독 처리에 사용되는 꿀벌의 품종은 이탈 리안 (Italian, Apis mellifera ligustica)종의 일벌 을 사용하였다. 일벌 중에서도 독낭 내의 봉독 량에는 일령별로 차이가 있어 독낭에 봉독이 충만된 연령인 소문출입 외역봉을 선택하였다 (조 등, 1998).

\section{(2) 자돈에 생봉독 주입방법}

시술용 이동봉상에서 핀셋으로 포획한 일벌 을 꺼내어 지정된 시술혈위에 벌이 살아있는 상태에서 접촉시켜 직접 쏘이게 하는 생봉직침 방법으로 시술하였다.

\section{7. 채혈}

채혈은 vacutainer (Becton Dickinson vacutainer systems, USA)를 이용하여 전대정맥에서 채혈 하였으며, Ig 농도 측정실험에서는 생시와 3 , 7, 14 및 21일령에 채혈하였고, $\mathrm{HC}$ 와 $\mathrm{AR}$ 항체 측정 실험에서는 $24,34,44,54$ 및 74 일령 때 채혈하여 실험실 까지 냉장 sampling box에 넣 어 신속히 수송한 다음 분석할 때까지 Ig 검사 용 혈액은 냉장 보관하였고, $\mathrm{HC}$ 와 $\mathrm{AR}$ 항체분 석용 혈액은 혈청을 분리한 다음 $-20^{\circ} \mathrm{C}$ 에 냉 동 보관하였다.

\section{8. 조사항목 및 조사방법}

\section{(1) Immunoglobulin 분석}

$\operatorname{IgG}, \operatorname{IgA}, \operatorname{IgM}$ 의 농도분석은 의료법인 이원 의료 재단에서 자동화 분석장비(Cobas Integra, Switzerland)를 이용하여 Immunoturbidimetric method에 의해 분석하였다(Becker 등, 1968 ; Bodansky 등, 1971 ; Lockitch 등, 1988 ; Brostoff 등, 1991 ; Johnson, 1993 ; Schumann 등, 1995).

(2) $\mathrm{HC}$ 항체가 분석

생봉독 처리군과 대조군에서 채혈된 혈액의 $\mathrm{HC}$ virus에 대한 항체검사는 ELISA kit법(金 등,
1994)에 의하여 충청북도 축산위생연구소에서 분석하였다.

(3) $\mathrm{AR}$ 항체가 분석

생봉독 처리군과 대조군에서 채혈된 혈액의 Bordetella bronchiseptica에 대한 항체검사는 test tube agglutination test법(金 등, 1994)에 의하여 충청북도 축산위생연구소에서 분석하였다.

\section{9. 통계분석}

본 실험에서 얻은 모든 결과는 SAS 일반 선 형모델 (general linear model)에 의해 분산분석 을 실시하였고 분산분석 결과 유의성이 인정되 는 부분에 대하여 Turkey's test 를 실시하여 처 리간 유의차를 검정하였다(SAS, 1990).

\section{III. 결과 및 고찰}

\section{Immunoglobulin 농도}

\section{(1) $\lg G$}

생봉독 처리가 자돈의 혈중 IgG 농도에 미치 는 영향은 Fig. 5와 같다. 분석결과 3일령부터 IgG 농도는 처리간에 유의차를 나타내기 시작 하였는데, 3일령의 IgG 농도는 생봉독 처리군 이 $368.48 \mathrm{mg} / \mathrm{dl}$, 대조군이 $334.14 \mathrm{mg} / \mathrm{dl}$ 로 생봉 독 처리군이 $10.3 \%$ 높게 나타났다 $(\mathrm{P}<0.02)$. 이 차 이는 7 일령에 $21.9 \%(\mathrm{P}<0.01), 14$ 일령에는 $18.0 \%$

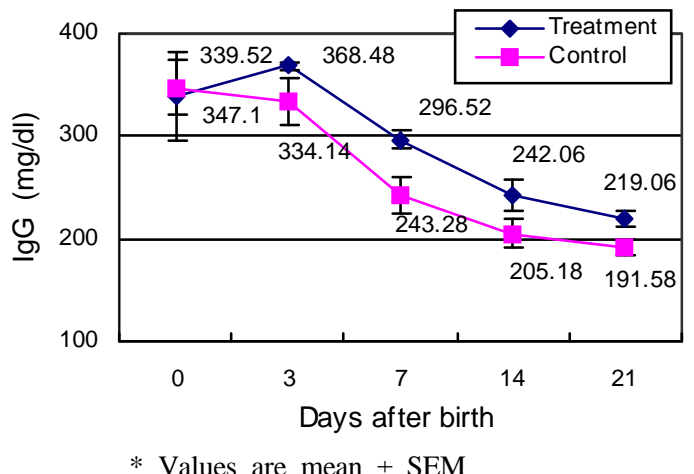

Fig. 5. Concentration of Immunoglobulin $G$ in piglets of honeybee venom treated and control group. 
$(\mathrm{P}<0.07), \quad 21$ 일령에는 $14.3 \%(\mathrm{P}<0.01)$ 로 생봉독 처리군이 대조군에 비해 높게 유지되었고 두 처리군 모두 시일이 경과됨에 따라 감소하는 경향을 보였다.

(2) $\lg A$

생봉독처리에 따른 자돈 혈중 IgA 농도 변화 는 Fig. 6과 같다. 혈중 IgA 농도는 생봉독 처 리군과 대조군이 본 실험 전기간에 걸쳐 별다 른 차이를 보이지 않고 비슷한 수준을 보였다. 14 일령 $(\mathrm{P}<0.70)$ 과 21 일령 $(\mathrm{P}<0.65)$ 에는 통계적인 차이는 없었지만 대조군이 약간 높게 나타났 다. IgA 농도는 IgG 농도와는 달리 시일이 지 나면서 오히려 약간 증가하는 경향을 보이다가 21일령에 생시수준으로 감소하는 경향을 나타 냈다.

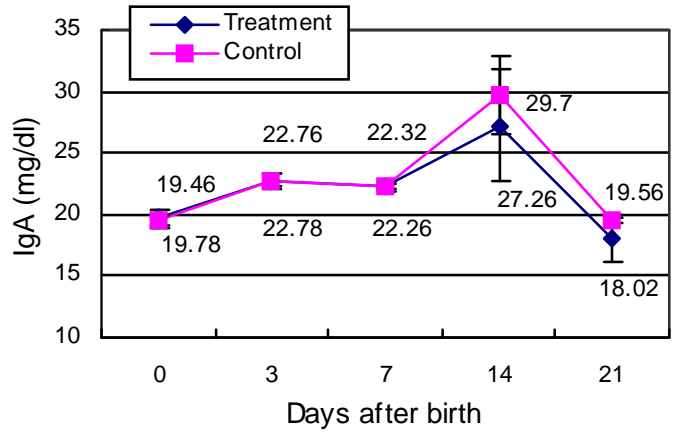

* Values are mean \pm SEM

Fig. 6. Concentration of Immunoglobulin A in piglets of honeybee venom treated and control group.

(3) $\lg \mathrm{M}$

생봉독 처리에 따른 혈중 $\operatorname{IgM}$ 농도의 변화 는 Fig. 7과 같다. IgM 농도는 생봉독 처리군에 서 대조군보다 전 실험기간에 걸쳐 약간 높은 수준을 보였는데 통계적인 차이는 없었다. 그 러나 유의차는 인정되지 않았지만 21일령 때의 $\operatorname{IgM}$ 농도는 생봉독 처리군에서 $4.20 \mathrm{mg} / \mathrm{dl}$, 대 조군이 $2.68 \mathrm{mg} / \mathrm{dl}$ 로 생봉독 처리군에서 $56.7 \%$ 높은 수준을 보였다 $(\mathrm{P}<0.53)$.

$\operatorname{IgM}$ 농도는 두 처리군에서 모두 시일이 지 나면서 감소하였다가 14 일령 부터 증가하는 경 향을 나타냈다.

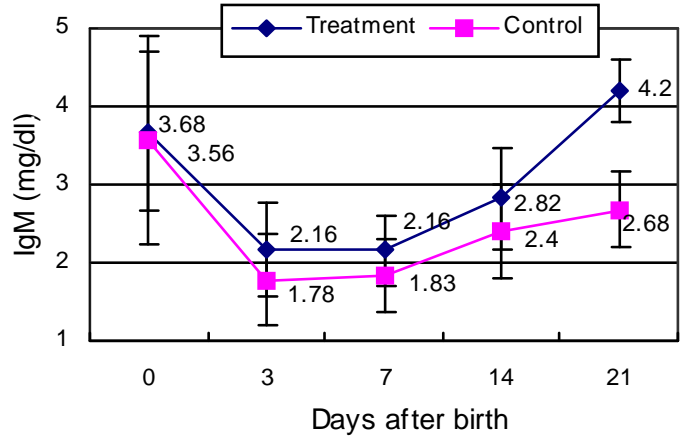

* Values are mean \pm SEM

Fig. 7. Concentration of Immunoglobulin $M$ in piglets of honeybee venom treated and control group.

\section{Hog cholera virus에 대한 항체가}

생봉독 처리가 $\mathrm{HC}$ virus에 대한 항체가에 미치는 영향은 Fig. 8과 같다. Antibody titer는 24일령 생봉독 처리군에서 647.53 , 대조군이 412.44로 생봉독 처리군이 $57.0 \%$ 더 높게 나타 났으며 $(\mathrm{P}<0.03)$, 34일령 처리구에서는 $74.6 \%$ 의 차이를 보였다 $(\mathrm{P}<0.006)$. 또한 44 일령에서는 $48.6 \%(\mathrm{P}<0.017)$, 54일령은 45.0\% $(\mathrm{P}<0.16), 74$ 일 령에서는 $44.4 \% \quad(\mathrm{P}<0.006)$ 가 높은 것으로 나타 났는데 54 일령을 제외하고는 고도의 유의차를 보였다. 모체 이행항체의 감소는 54일령까지 계속되었는데 생봉독 처리군의 감소정도가 대 조군에 비하여 적은 것으로 나타났다.

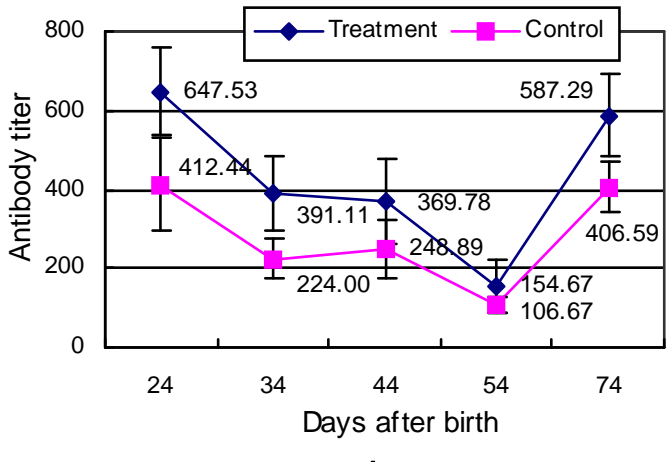

* Values are mean 土 SEM

Fig. 8. Antibody titer against hog cholera virus in piglets of honeybee venom treated and control group. 


\section{Bordetella bronchiseptica에 대한 항체가}

생봉독이 Bordetella bronchiseptica에 대한 항 체가에 미치는 효과는 Fig. 9와 같다. Antibody titer는 24일령 $(\mathrm{P}<0.32)$ 때를 제외하고 전기간에 걸쳐 생봉독 처리군의 항체가가 높게 나타났는 데 모두 고도의 유의성이 인정 되었다. 생봉독 처리군은 대조군에 비하여 34일령에는 $39.7 \%$ $(\mathrm{P}<0.002), 44$ 일령은 $31.9 \%(\mathrm{P}<0.02), 54$ 일령에서 는 33.4\% $(\mathrm{P}<0.01), \quad 74$ 일령에는 $57.3 \%(\mathrm{P}<0.007)$ 로 높은 항체수준을 보였다.

Bordetella bronchiseptica에 대한 모체 이행항 체의 감소 현상에서도 $\mathrm{HC}$ 에서와 마찬가지로 54일령 때까지 계속되었는데 생봉독 처리군의 감소정도가 더 적은 것이 관찰되었다.

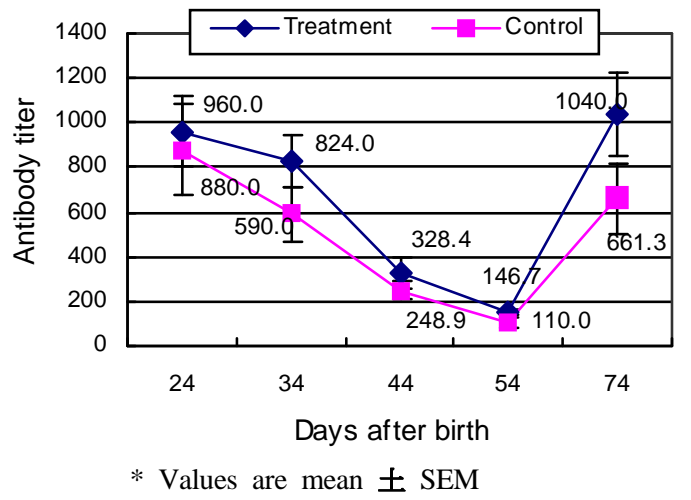

Fig. 9. Antibody titer against Bordetella bronchiseptica in piglets of honeybee venom treated and control group.

$$
\text { IV. 고 찰 }
$$

Immunoglobulin(Ig)은 외부의 이물질로부터 생체 를 방어하는 역할을 한다. Ig는 항원과 결합하 는 부위인 Fab (fragment antigen binding) portion 과 면역계 세포와 상호 작용하는 Fc (fragment crystallizable) portion 및 보체인자를 함유하고 있다.

Fab 부분은 toxin이나 bacteria, virus와 같은 항 원을 인지하여 toxin을 중화하고 immunocompetent cell의 감작 작용 및 viral infectivity를 감소시키 는 역할을 한다.

이들 Ig는 heavy chain 구조에 따라 IgM, IgG,
IgA, IgD, IgE 등 5 종류의 isotypes으로 나뉘어 진다. IgG는 주로 혈중과 체액에 존재하면서 toxin을 중화하고 세균을 고정하며, virus를 중 화하는 등 체내 면역에 중요한 역할을 한다.

IgA는 눈물, 타액, 땀, 유선, 장 또는 호흡기 점막 등에 존재하는 항체로 점막에서 면역작용 을 하고, IgM은 혈액중에 존재하며 세균에 대 한 방어 역할을 하고, toxin 중화능력도 있지만 $\mathrm{IgG}$ 에 비하여 매우 약하다.

IgD는 B lymphocytes의 표면에 존재하고 혈 액에는 미량이 존재하는데 $\mathrm{IgD}$ 의 역할에 대하 여는 알려져 있지 않다. IgE는 혈중에 낮은 농 도로 존재하며 allergy 과민반응에 관여하는 것 으로 알려져 있다(Benjamini 등, 1996).

본 실험에서 생봉독 처리가 이들 Ig 중에서 면역작용에 중요한 역할을 하는 IgG, IgA와 $\mathrm{IgM}$ 의 농도에 미치는 영향을 분석한 결과는 Hoffmann 등(1997)과 Curcio 등(1997)은 봉독이 체액성 면역반응을 증강시켜 면역력 상승에 효 과적이었다고 보고와 유사하였으며, Light 등 (1997)도 벌 관리자 혹은 지속적으로 봉침시술 을 받은 사람에서 IgG 항체 농도가 증가하였다 고 보고와도 동일한 결과를 나타냈다. 또한 Artemov(1967)도 봉독은 포유동물의 면역계를 자극하여 항병력을 높인다고 하였고, Belleveau 등(1982)은 동물의 암세포 치료에 적용한 결과 봉독 자체는 암세포에 직접적 작용은 없었으나 간접적으로 면역계를 자극시켜 치료효과가 있 다는 것을 증명한 바 있다.

본 연구에서도 생봉독을 처리한 군에서 대조 군에 비해 IgG 농도의 증가가 관찰되었는데 이 는 Light 등(1997)의 보고와 유사한 결과를 나 타냈다.

다만 조사결과 생봉독 처리군의 IgA 농도수준 이 대조군과 비슷하게 나타난 것은 IgA는 혈중 보다는 점막에 존재하는 항체이기 때문에 혈중 농도에서 차이를 보이지 않은 것이라 사료된다.

그러나 생봉독 그 자체도 좋은 항원이기 때문 에 생봉독 처리에 의한 IgG 농도 증가를 면역능 력의 직접적인 증가인 것으로만 해석하기는 어 렵다. 이러한 이유 때문에 지표항원으로 돈콜레 라와 위축성비염 백신을 주사하고 돈콜레라 
virus와 위축성비염 원인균인 $B$, bronchiseptica 에 대한 항체가를 조사한 결과 본 실험에서도 생봉독 처리군이 대조군에 비하여 hog cholera virus와 $B$, bronchiseptica에 대한 항체가가 유의 적으로 높은 수준을 보였다.

이러한 결과는 Artemov(1967), Hoffmann 등 (1997) 및 Curcio 등(1997)의 봉독이 체액성 면 역반응을 증강시키는 작용이 있다는 보고와 일 치하였다.

이상의 결과에서 생봉독 처리는 돼지의 면역기 능을 증강시키는 효과가 있음이 입증되었다. 다 만 본 실험에서는 생봉독 처리가 체액성 면역에 미치는 영향에 대해서만 조사되었으므로 정확한 면역반응 기전을 밝히기 위하여 앞으로 세포성 면역에 미치는 영향에 대한 연구도 요구된다.

\section{V. 요 약}

본 실험은 생봉독 처리가 돼지의 체액성 면 역반응에 대한 생봉독의 효과를 조사하기 위하 여 실시하였다. 혈중 Immunoglobulin(Ig) G, IgA, $\mathrm{IgM}$ 의 농도에 미치는 생봉독의 효과를 조사하 기 위하여 모돈 3 두에서 생산한 자돈 20 두(LY $\times \mathrm{D})$ 를 생봉독 처리군과 대조군으로 각각 10 두 씩 배치하였다. 생봉독 처리군은 출생시와 3 일 령에 교소혈 (GV-1), 해문혈(ST-25) 및 두구혈 (CV-8), 6일령에 거세, 단미 창상부위에 생봉 1 마리씩 직침 시술하였고, 대조군은 생리식염수 $1 \mathrm{ml}$ 를 동일한 혈위에 주입하였다. 혈중 Ig 농 도 측정을 위하여 출생시와 3 일, 7 일, 14 일 및 21일령에 채혈하여 Immunoturbidimetric method 로 $\operatorname{IgG}, \operatorname{IgM}, \operatorname{IgA}$ 를 측정하였다.

지표항원으로 사용한 돈 콜레라와 위축성비 염 백신에 대한 생봉독의 항체 생성효과를 조 사하기 위하여 모돈 5 두에서 생산된 자돈 40 두 $(\mathrm{LY} \times \mathrm{D})$ 를 생봉독 처리군과 대조군으로 각각 20 두씩 공시하였다. 생봉독 처리군은 출생시에 교소혈(Jiao-Chao, GV-1), 해문혈(Hai-Men, ST-25) 및 두구혈(Du-Kou, CV-8)에, 3일령에 단미 및 거세시술 시 창상부위에 생봉독을 처리하였고, 21일령 이유시에는 교소혈(GV-1)과 백회혈(BaiHui, GV-20)에 생봉독을 처리하였다. 지표항원
으로 위축성비염 백신은 24일령과 44일령에 접 종하였고 돈콜레라 백신은 44일령과 64일령에 각각 접종하였다. 항체가 분석용 혈액은 24,34 , 44, 54 및 74일령에 채혈하여 위축성비염은 시 험관응집반응, 돈콜레라는 ELISA법에 의하여 항체가를 조사하였다.

IgG 농도는 처리군에서 출생시 339.52, 3일령 에 366.48, 7일령에 296.52, 14일령에 242.06, 21 일령에는 $219.06 \mathrm{mg} / \mathrm{dl}$ 이었고 대조군은 각각 347.10, 333.14, 243.28, 205.18 및 $191.58 \mathrm{mg} / \mathrm{dl}$ 이었다. 처리전(출생시)에는 처리군과 대조군간 에 유의차가 없었으나 처리군의 IgG 농도가 대 조군에 비하여 3 일령 $10.3 \%(\mathrm{P}<0.02)$, 7일령에 는 21.9\% (P<0.01), 14일령에는 18.0\% ( $<<0.07)$, 21 일령에는 $14.3(\mathrm{P}<0.07)$ 더 높게 나타났다. IgA 와 IgM의 농도는 전체기간동안 처리군과 대조 군간에 유의차가 인정되지 않았다.

돈콜레라 virus에 대한 항체역가는 처리군에 서 대조군에 비하여 24일령 때 $57.0 \%(\mathrm{P}<0.03)$, 34 일령 때 $74.6 \%(\mathrm{P}<0.006)$, 44일령에 $48.6 \%$ $(\mathrm{P}<0.017)$, 54일령 때 45.0\% $(\mathrm{P}<0.16)$, 74일령 때 $44.4 \%(\mathrm{P}<0.006)$ 가 유의하게 높은 것으로 나타 났다.

위축성비염 원인균인 Bordetella bronchiceptica 에 대한 항체역가는 처리군이 대조군에 비하여 34 일령 때는 39.7\% (P<0.002), 44일령 때 31.9\% $(\mathrm{P}<0.02)$, 54일령 때에 $33.4 \%(\mathrm{P}<0.01), 74$ 일령 때에는 $57.3 \%(\mathrm{P}<0.007)$ 가 높게 나타나 접종일 인 24일령을 제외하고 전체기간에 걸쳐 높은 항체수준을 보였다.

위의 결과를 종합해 볼 때 돼지에 대한 생봉 독 처리는 면역기능향상 효과가 있는 것으로 사료된다. 이와 같은 결과를 볼 때 돼지에 대 한 생봉독의 처리는 양돈 생산성면에서 생봉독 처리는 돼지의 생존율을 높이고, 증체량이 높 았다는 조 등(2005)의 보고를 뒷받침하고 있어 양돈 산업발전에 기여할 것으로 사료된다.

$$
\text { VI. 사 사 }
$$

이 논문은 2005년도 충북대학교 학술연구지 원사업의 연구비 지원에 의하여 연구되었으며 
연구비 지원에 감사드립니다.

\section{VI. 인 용 문 헌}

1. Artemov, N. M. and Orlov, B. N. 1967. New data to scientifically support the physiological use of bee venom as a medicine. In : Proceeding in the XXI International congress : p.p. 348-353.

2. Barker, S. A. 1966. Separation and isolation of the hyaluronidase and phospholipase components of bee venom and investigation of bee venom human serum interactions. Clin. Chim. Acta. 13:582-596.

3. Becker, W., Rapp, W., Schenk, H. G. and Storiko, K. 1968. Methden zur quantitativen bestimmung von plasmaproteinen dutch Immunoprilzipitation. Z. Klin. Chem. Biochem. 6:113-122.

4. Belliveau, J. F. 1982. The comparison of bee venom fraction by their layer isoelective focusing. NAAS. Proceedings 5:34-37.

5. Benjamini, E., Sunshine, G. and Leskowitz, S. 1996. Immunology a Short Course. Wiley-Liss. New York. p.p. 57-92.

6. Bodansky, O. and Lamer, A. L. 1971. Advance in clinical chemistry. Academic press. New York. 14:219-317.

7. Brostoff, I., Scadding, G. H., Male, D. and Roitt, I. M. 1991. Clinical immunology. Gower Medical Publishing. London. p.p. 11-18.

8. Curcio, V., Onlanthen, V., Schneider, C. H., Frutig, K., Blaser, K. and Kalbacher, H. 1997. Moecular parameters in melittin immunogenicity. J. Pept. Sci. 3:267-276.

9. Doery, H. M. 1964. Phospholipase B in snake venoms and bee venom. Biochem. J. 92:599-602.

10. Dunn, J. D. and Killion, J. J. 1988 $8^{\mathrm{a}}$. Effect of melittin on pituitary adrenal responsiveness to stress. Acta. Endorinol. (Copenh). 119:339-344.

11. Dunn, J. D. and Killion, J. J. 1988 ${ }^{\mathrm{b}}$. Melittinevoked increase in plasma corticosterone levels. Life Sci. 43:335-343.

12. Gauldie, J., Hanson, J. M., Rumjanek, F. D., Shipolini, R. A. and Vernon, C. A. 1976. The peptide components of bee venom. Eur. J. Biochem. 61:369-376.

13. Gauldie, J., Hanson, J. M., Shipolini, R. A. and Vernon, C. A. 1978. The structures of some peptides from bee venom. Eur, J. Biochem. 83:405-410.

14. Habermann, E. and Reiz, K. G. 1965. On the biochemistry of bee venom peptides, melittin and apamin. Biochem. Z. 343:192-203.

15. Hanson, J. M., Morley, J. and Herrera, C. S. 1974. Anti-inflammatory property of 401(MCDpeptide) a peptide from the venom of the bee, Apis mellifera. Br. J. Pharmacol. 50:383-392.

16. Hoffmann, P., Loleit, M., Mittenbuhler, K., Beck, W., Wiesmuller, K. H., Jung, G. and Bessler, W. G. 1997. Induction of an epitope-specific humoral immune response by lipopeptide hapten conjugates: enhancement of the anti-melittin response by a synthetic T helper (Th)-cell epitope. FEMS. Immunol. Med. Microbial. 17:225-234.

17. Jentsch, J. 1969. Further studies on the amino acid sequence of melittin. 3. Hydrolysis with highly purified trypsin. Z. Naturforsch. 24:264-265.

18. Jentsch, J. 1972. Phospholipase A (EC 3. 1. 1. 4) from bee venom. II. At least two phospholipases A in bee venom. Justus Liebigs Ann. Chem. 757:187-192.

19. Johnson, A. M. 1993. A new international reference preparation for proteins in human serum. Arch. Pathol. Lab. Med. 117:29-31.

20. Kim, C. M. H. 1986. Bee venom therapy managing pain and stress. 1:1-5.

21. Kim, C. M. H. 1987. Bee venom therapy for arthritis and neuritis pain. Supp. 4, 262.

22. Light, W. C., Reisman, R. E., Shimizu, M. and Arbesman, C. E. 1977. Clinical application of measurements serum level of bee venom specific IgE and IgG. J. Allergy. Clin. Immunol. 59:247-253.

23. Lockitch, G., Halstead, A. C., Quigley, G. and MacCallum, C. 1988. Age and sex specific pediatric reference intervals; study design and methods illustrated by measurement of serum proteins with the behring LN nephelometer. Clin Chem. 34: 
1618-1621.

24. Lowy, P. H. 1971. Polypeptides minimine and melittin from bee venom : effects on drosophila. Arch. Biochem. Biophys. 145:338-343.

25. Nelson, D. A. 1963. The kenom of the honey bee (Apis mllifera) free amino acids and peptides. Canad. J. Biochem. 46:1221-1226.

26. O'Connor, R. and Peck, M. L. 1978. Venoms of the apidae. In Bettin S, Handbook of Experimental pharmacology, Springer-Verlag. Berlin. 48:chaper 21.

27. Owen, M. D. 1971. Chemical components in the venom of Ropalidia Revolutiomalis and Polistes Humilis (Hymenoptena, Vespidae). Toxicon. 17: 519-523.

28. Owen, M. D. 1974. A quantitative and temporal study of histamine and histidine in honey bee (Apis mellifera L.) venom. Can J. Zool. 52:387-392.

29. Owen, M. D. and Bridages, A. R. 1982. catecholamines in Honeybee (Apis mellifera L.) and various vespid (Hymen-optera) venoms. Toxicon. 20:1075.

30. Peck, M. L., Oconnor, R., Johnson, T. J., lsabell, A. F., Martell, A. E., McLendon, G., Neff, R. D. and Wright, D. A. 1978. Radioprotective potential and chelating properties of glycylhi-samine and analog of histamine terminal peptides found in bee venom. Toxicon. 16:690-694.

31. Rudenko, S. V. and Nipot, E. E. 1996. Modulation of melittin-induced hemolysis of erythrecytes. Biokhimiia. 61:2116-2124.

32. SAS. 1990. SAS procedures Guide for personal computers, Version 6 Edition. SAS institute Inc.

33. Schumann, G. and Dati, F. 1995. Vorlaufige Referenz-bereiche fur 14 protein im serum (fur erwachsene) nach standardisierung immunchemischer methoden unter bezug auf das internationale referenzmaterial CRM 470. Lab Med. 19:401-403.

34. Shkenderov, S. H. 1973. Protese inhibitor in bee venom. Identification partial purication and some properties. FEBS Lett. 33:343-347.
35. Shkenderov, S. H. 1982. Adolapin-a newly analgetic and antiflammatory polipeptide from bee venom. Toxicon. 20:317-321.

36. Shkenderov, S. H. and Todarv, S. 1979. Effect of bee venom and its low and high molecular fraction on embryogenesis in rats. Eksp. Med. Mor. for. 18:160-165.

37. Steiner, H., Hultmark, D., Engstrom, A., Bennich, H. and Boman, H. G. 1981. Sequence and specificity of two antibacterial proteins involved in insect immunity. Nature. 292:246-248.

38. Vick, J. A., Brooks, B. and Shipman, W. 1972. Therapeutic applications of bee venom and Its components in the dog. American bee journal. 11 :414-416.

39. 李長卿．苑文學．1989．中國獸醫銊食圖譜．甘肅 科學技術出版社. 甘畫省. p.p. 115-123.

40. 竹中良二, 高橋貢. 1984. 中國獸醫鍼尒學. 文永 堂. 東京. p.p. 156-183, 262.

41. 강성수, 최석화, 조성구. 1999. 관절염 유발 랫드 에 대한 생봉독의 치료효과. 한국임상수의학회지 16:155-162.

42. 김문호. 1992. 봉독요법과 봉침요법. 한국교육기 획. 서울. p.p. 20-103.

43. 김병한, 탁동섭, 송재영, 최강석, 안동준, 현방훈, 안수환. 1994. 돼지콜레라 항체검사법 개량연구. 수의과학 시험연구보고서. 농촌진흥청. p.p. 185190.

44. 조성구, 권영방, 최석화. 1998. 생봉독 주입에 의 한 가축의 다발성 질환 치료법 개발. 농림부 농 업기술개발센터. p.p. 22-25.

45. 조성구, 김경수, 이석천. 2005. 생봉독 처리가 돼 지의 생산성에 미치는 효과. 한국동물자원과학회 지. 47(2):293-304.

46. 최석화, 강성수. 1998 . 단미창상의 생봉독 요법. 한국임상수의학회지. 15:247-250.

(접수일자 : 2006. 8. 30. / 채택일자 : 2006. 11. 9.) 